\title{
From April 10, 2010 to Date: Nicha Hiranburana Thuvatham's Struggle for Justice through Media for her Late Husband
}

\author{
Pogkrong Boon-Long \\ MA Program in Women, Gender and Sexuality Studies, College of Interdisciplinary Studies, \\ Thammasat University, Bangkok, Thailand
}

Doi:10.5901/jesr.2014.v4n4p278

\begin{abstract}
On November 1, 2013, around 4 o'clock in the morning, PM Yingluck Shinawatra's government attempted to force the Thai Parliament to pass an amnesty bill to whitewash the act of criminals, rioters and others who committed unlawful acts while gathering in political protest over the period from 2004 until August 8, 2013. This attempt had terrible consequences for the justice issues affecting those who were killed in those incidents, including General Romklao (Christopher) Thuvatham, who was fatally shot while performing his duty, unarmed, at Khok Wua Intersection in Bangkok on April 10, 2010. Consequently, such an operation by the PM and her government pushed Nicha Hiranburana Thuvatham, General Romklao's wife, on presenting her grievances via the media, to plead for justice for her late husband. This paper aims to analyze Nicha's strategies in her combined roles as wife, citizen and government officer in struggles with Thai government over the issue of justice. The analysis was made using Nicha's public speeches selected from the three media: her address to the forum of the People's Democratic Reform Committee televised on BlueskyTV on November 24, 2013; an interview with Pak-Soi-Roi-Neung, a radio program aired on January 20, 2014; and a letter Nicha wrote to the wife of Suthin Tarathin, the renowned social activist assassinated while participating in a protest for advance voting for the national election on January 26, 2014. Also considered were some parts of Nicha's narrative in the book named In the Memory of Love which she published for the first anniversary of her husband's death.
\end{abstract}

Keywords: Grief, Ideology, Loss, Media, Nicha Hiranburana Thuvatham, Woman in Thai Political Movement

\section{Introduction}

Since April 10, 2010, when disciplinary Colonel Romklao (Christopher) Thuvatham was fatally shot in the hazardous riot at Khok Wua Intersection on Rajadamnern Avenue in Bangkok while performing his duty, unarmed, for Thai Army and the government, the investigation into the case has made little progress. The riot took place at the site where the group of people calling themselves "Red-Shirts" gathered to protest PM Abhisit Vejjajiva on his political performance. PM Abhisit, who concentrated very much on pursuing the killing of civilians by government officers, ordered soldiers to perform their duties at the site unarmed. Shamefully, to date, the real killer of Colonel (posthumously promoted to General) Romklao has not been brought to justice. Only mentioned as a suspect at the time was "the guy in a black shirt."

At that time, Nicha Hiranburana Thuvatham, the wife of General Romklao, has tried hard to plead for justice from PM Abhisit's government for her late husband, and has struggled for years with the issue since then through the period of PM Yingluck Shinawatra's government, which began their administration in August 2011, and made the hasty attempt, on November 1, 2013, around 4 o'clock in the morning, to force the Thai Parliament to pass an amnesty bill to whitewash the act of criminals, rioters and others who committed unlawful acts while gathering in political protest over the period from 2004 until August 8, 2013. The period of time covered by the amnesty in the act drafted by PM Yingluck's government included the coup d'état of September 19, 2006, against the government of PM Thaksin Shinawatra, the elder brother of PM Yingluck, who was sentenced to prison for committing a corrupt act against the Kingdom of Thailand and who fled justice and remains a fugitive outside the country. Thaksin had received support from a great number of people in Thailand, including many in the "Red-Shirt" group, which positioned themselves on the opposite side of the "Yellow-Shirt" group due to their different perspectives on politics. From the time of their first protest gatherings publicized worldwide on media, the "Yellow-Shirts" were labelled as a non-violent movement while the "Red-Shirt's" image was tarnished by violence and destruction (Nostitz, 2011: 11-35), largely evident in their setting fire to several large shopping centres and one of the oldest cinemas in downtown Bangkok on May 19, 2010. It went without saying that one of the persons who profited from the suspicious amnesty bill proposed by PM Yingluck was her elder brother, the ex-prime minister of Thailand who remained a fugitive from justice of crimes against the state of Thailand (McCargo, 2009; Surin, 2007).

Evidently, General Romklao was a victim who would have failed to receive justice by the amnesty bill, and this strongly motivated Nicha to resist the government's efforts once the news of its dubious attempts to pass the act were 
disclosed to the public. Nicha has pleaded for justice on behalf of General Romklao and herself directly to PM Yingluck's government, and to social organizations involved, such as Office of the National Human Rights Commission of Thailand, but investigations into the case remained stalled. As a form of amends for Nicha's loss, the Yingluck government promoted her to a high-level government position that was permanent rather than the temporary appointment made during the set by a political incident. From the position of Director of the Central Administration, Office of the Permanent Secretary, Ministry of Science and Technology, she was elevated to the position of Advisor to Prime Minister, the Department of Permanent Senior Official on Social Issues in the work group of Strategy and Machination at the Secretariat of the Prime Minister in the Office of the Prime Minister, which was her former position before being transferred to Ministry of Science and Technology. Nicha considered such efforts by the government to placate her could never compensate for the injustice she and her husband had received and the hasty attempt of the government to pass the amnesty bill on November 1, 2013 certainly encouraged Nicha to shout out louder for justice. Appearing often in the media during that critical period of time, Nicha, as a senior officer in the governmental organization seemed to have no fear of being dismissed from her position. On the contrary, she used her status to fortify her mission through the entire range of media, and by taking part in the political movement supported by millions at home and abroad, seeking the elimination of corruption and corrupt politicians, and reform in Thai society. The underhanded attempt to pass amnesty bill shrouded ambitious efforts by government members to garner profits from corrupt practices and rob the country (DP Youth Center, 2013). Through her struggle on behalf of the late General Romklao, Nicha has naturally made use in many ways of the great support she has received from opponents of the Yingluck's government.

\section{A Critical Struggle for Justice in Thailand before Nicha's Case}

The mysterious disappearance of lawyer Somchai Neelapaijit since March 12, 2004, without trace, clearly reflects a failure in the operation of the law in Thailand. The article, The Disappearance of Lawyer Somchai Neelapaijit (Nakarin, 2011), raised a presumption on one of the most critical reasons for the lawyer's "being disappeared," a phrase coined by his wife, Angkhana Neelapaijit. It relates to the legal appeal which revealed the illegal mistreatment by a group of governmental officers of a group of crime suspects in several public security cases. These officers, presumably, of the police, violently abused their legal powers, as mentioned in the article, by having a third person urinate over the suspects' faces, and having the suspects tortured by electrical charges to their bodies and genitals, to force them to make confessions. Consequently, according to judicial documents, lawyer Somchai, who was handling the suspects' cases, pleased in court, for a judicial order to have his clients transferred to penal rather than police custody. The following day, Somchai disappeared. This incident took place during the term of Thaksin Shinawatra's government.

For a great number of Thai citizens, lawyer Somchai's case is a tragedy of justice. This case has essentially manifested Angkhana Neelapaijit's courage and strong determination in the face of fruitless search for her missing husband over the past decade. Angkhana, a common Islamic civilian, has struggled to marshal action from the police to fully investigate lawyer Somchai's mysterious disappearance, and, has frequently resorted to pleas for government intervention beginning with that under the authority of PM Thaksin which paid scant attention to the case from the start. Moreover, police investigation into the case and prime suspects since the early stages was riddled with flaws (Nakarin, 2011). In 2005, the case was transferred to the Department of Special Investigation (DSI), but the investigation continued to make little progress. To date, no remains have been found of lawyer Somchai, who, believed by many people, would be killed.

Angkhana's loss is a key human rights issue. Her husband's case has been one of concern for a number of noteworthy international organizations such as the United Nations (UN), and Organization of Islamic Cooperation (OIC). Even though the Thai government under PM Yingluck formally signed the United Nations' International Convention for the Protection of All Persons from Enforced Disappearance, on January 9, 2012 ("Thailand signs the International Convention on the Protection of All Persons from Enforced Disappearance," 2012) to reinforce its human rights credentials with respect to disappearances, and even though Angkhana and her family were offered 7.5 million baht in compensation, Angkhana was not satisfied with this response. Her position on the stated issue was partly declared in an open letter written on March 10, 2013, addressed to PM Yingluck as chairman of Special Investigation Committee call on the DSI to fully investigate her husband's disappearance. Angkhana's declaration contained the following point:

\footnotetext{
"...anyway, on providing a treat to the bereaved, only money cannot completely erase the victims' memories of severe wounds. I strongly believe that only the chance to get to the truth, and only justice can bring their own dignities back to them, and that should lead all to the real forgiving and lasting harmony.
} 
I write this letter to Your Excellence, who has taken the position of the country's top executive and has commanded DSI, to inform you of the incapability and the nonchalance of the government and DSI on conducting the practical investigation into lawyer Somchai Neelapaijit case. ..." ("From the bottom of Angkhana's heart to 'Poo [the PM Yingluck's nickname], the Rotten Rice' on lawyer Somchai's disappearance case and DSI," 2013)

Similarly, General Romklao's case is another way to which PM Yingluck's government paid improper attention. Their hasty efforts to pass the amnesty bill in the early morning of November 1, 2013 with its stated aim clearly reflected their negligence and failure to act responsibly in the interests of justice for all, including General Romklao; whereas, had the bill been passed it would have been Thaksin Shinawatra, PM Yingluck's fugitive brother, who, would have stood to benefit most (Thompson, 2014). The corrupt act of PM Yingluck's government pushed Nicha to join millions of them to create one of the most important political movements in Thai political history, in a call for reform and, in her case, justice for her husband savagely Gunned down in the heart of Bangkok.

This paper aims to analyze Nicha's strategies in her struggle with PM Yingluck's government over the issue of justice for her late husband and herself. The analysis is made using Nicha's public speeches selected from three media: her address to the forum of the People's Democratic Reform Committee televised on BlueskyTV on November 24, 2013 (LiveTV0012Th, 2013; "Nicha urges government officers to take responsibilities for their duties and suggests 'Poo' who has never bereaved her own husband to take back her words on forgiving the convict, 2013); an interview with Pak-SoiRoi-Neung (2014), a radio program aired on January 20,2014; and a letter Nicha wrote to the wife of Suthin Tarathin ("Nicha feels sympathy with the bereaved and writes a letter to encourage Suthin's wife to stand firm for 'Look-Kaew,' " 2014), the renowned social activist assassinated while participating in a protest for advance voting for the national election on January 26, 2014. Some parts of Nicha's narrative in the book named In the Memory of Love (Nicha, 2011), which she published for the first anniversary of her husband's death, were also considered. The great inspiration for the author of this paper, one of countless Thai citizens who signed a petition opposing the amnesty bill, came in the form of a booklet entitled Luang-Poo-Fark-Wai (Prarajawarakhun, n.d.) provided to those people who took part in Buddhist chanting at the New Year Festival of 2011 at Temple of the Emerald Buddha, Bangkok. The booklet, which was specially published for General Romklao's royal cremation ceremony, reminded me of his heroism. In addition, I personally experienced elements of the chaotic riot on April 10, 2010, as a pedestrian nearby where the incidents took place and witnessed the sound of gun fire in the vicinity. Traffic in the neighborhood near the site was blocked in all directions for a distance of 5-10 kilometers. The incident forced all pedestrians to flee for their lives. I came to realize that what partly saved me on that day, was the sacrifice of soldiers, including General Romklao, who put their lives at risk to control the situation. Essentially, what has driven me to develop this paper is my personal and academic interest in the field of women, gender and sexuality studies, and the social role and endeavours of such a woman in contemporary Thai society as Nicha Hiranburana Thuvatham.

\section{Nicha's Strategies in Struggles with Thai Government over the Issue of Justice for her Late Husband}

In the selected media, Nicha's speeches and writings call for justice for her late husband and, it can clearly be seen that she took part in political activities together with the mass of protesters against the Yingluck government. Her first media event was a speech aimed directly at protestors at the PDRC forum. This was followed by an interview given for a radio program about attending the cremation of Prakong Chujan, a forty-six-year-old PDRC protestor from Phuket Province, who died after receiving a blow to the head at a PDRC parade, not far from the National Stadium, on Bantardthong Road. In the interview, Nicha shared her experience of bereavement along with Prakong's wife. Among the selected media in this context is the letter which Nicha, as widow to an unarmed husband who was fatally shot, wrote to Yao, the wife of Suthin Tharatin, social activist and chief developer guard of the Army of People to Wipe Out Thaksin Regime, who also died of a gunshot wound while leading a protest for advance voting for the national election on January 26, 2014, around Sri-ieam Temple in Bang Na District. The letter aimed to encourage Yao to stand firm for the sake of her young daughter and shared her grief with other bereaved members of the community, which, in this context, was a community of people who held the same political views, and shared their grief and frustration with one another.

Nicha's grief was a sentiment, which, according to John Bowlby (1973, cited in Walsh, 2012: 66), is “...the reaction of the bereaved to the loss of a significant other." General Romklao passed away in the chaotic riot which can be considered a traumatic event which caused a traumatic loss (Travers, Ali, \& Kolkiewicz, 2013: 223-4; Walsh, 2012: 118) for Nicha. In a certain way, the PDRC forum and the masses which took part in the political movement are, in this context, akin to bereavement counseling which offered Nicha an opportunity to share her experience of bereavement, including intimate expressions, among members in the same community, especially of grief (Hall, 2014: 12; Walsh, 2012: 105)

The strategies Nicha used in her struggles with PM Yingluck's government over the issue of justice for General 
Romklao and herself were fundamentally guided by grief, and the opportunities that arose from the political movements against the corrupt practices of government. In this context, Nicha, as a woman, employed strategies available in everyday life to fight in an arena which was conditioned under the established power relationship (Juree, 2008: 32; Suteera, \& Maytinee, 2008: 57) by challenging and condemning the Yingluck government which performed the corrupt acts. At the same time, Nicha created an alliance with the masses who suffered equally from corruption and a government, which paid a little attention to the problems and harm caused by their corrupt acts, and selfishly took advantages of the public for their own benefit, as later clearly evidenced by the ruinous losses attributed to the rice mortgage scheme. The masses also lost group members from violent attacks against which the government completely failed to take protective action or initiate legal investigation. Nicha, as a citizen under submission to a corrupt government, shared the common and universal grief of the masses. To solidify these strategies, Nicha demanded justice for her husband and herself by presenting her loss and grief from the standpoint of a wife, government officer and citizen of the Kingdom of Thailand. The essential phrase, "Deep from the heart which bereaved the same," ("Nicha feels sympathy with the bereaved and writes a letter to encourage Suthin's wife to stand firm for 'Look-Kaew,' " 2014) in the letter Nicha wrote to Yao, Suthin's wife, significantly reflects Nicha's status as an intimate and sincere member of this mass community. Besides, that phrase seems to indicate a sharing and healing process as part of the grief relief that Nicha and Yao underwent in their bereavement. Naturally, the grief, which Nicha experienced, and which was collectively shared served to further raise the heroic profile of General Romklao as a brave and disciplined senior commander of the Royal Thai Army.

Nicha's strategies to establish justice for her late beloved husband via the media highlighted the value of courage in the fight to regain peace and Dharmic principles, and corruption free pride in national dignity. Her speeches and writings selected for study place prime importance on bravery and sacrifice by which the masses pursued their mission to topple a government which had ruled the country illegitimately. She praises the masses for carrying out their quest according to the Buddhist principles of ahimsa (non-violence). In the book, entitled In the Memory of Love (2011) published to commemorate the first anniversary of her beloved husband's death, she stressed his bravery and great sacrifice as a soldier who held high respect for his commanders and provided boundless care to his subordinates.

Widow Nicha comforted and encouraged the PDRC supporters to stand united against the "dark hazard," a reference to ruthless acts of violence masterminded by corrupt politicians and perpetuated by thugs. Overcoming fear, according to Nicha, signaled victory of sorts for the masses and herself. Nicha confidentially stressed that a government was only able to gain the respect and confidence of the faith from people by governing the nation with ethics and morals, especially honesty. In addition, Nicha saluted Prakong, on Pak-Soi-Roi-Neung, and Suthin, in her letter to his wife, as the kingdom's heroes who truly loved their motherland and sacrificed their lives for their beloved families and the nation. At PDRC fora, Nicha, by referencing the sacrifices of her beloved husband and the loss of Prakong's family, also solemnly advised the crowds to wisely manage the anger they felt in loss and frustration. Nicha considered such advice provided a more practical and powerful way to fight the criminals and corruptors than wielding guns or other lethal weapons. This approach won the hearts and minds of her audience and uplifted their spirits. She strongly believed that this method could lead the beloved souls of the deceased such as her husband and Prakong, to rest in peace in Buddhist tranquility.

Moreover, at PDRC fora, Nicha, who declared her status as a government officer and a Thai citizen who could not let the kingdom fall into ruins before her eyes, urged supporters to their standing as citizens lucky enough to live in the kingdom that had protected generations of ancestors, and been governed by a succession of morally upstanding rulers, for a very long time. She hoped that this realization could be harnessed as a force to resist the corrupt government and its minion ruler. Nicha essentially demonstrated her determination to underscore the virtue of their mission by emphasizing that General Romklao's death came while performing his duty as a Thai government officer. Importantly, she asked all Thai government officers to preserve their professional dignity and the state's independence by not cooperating with or submitting to the demands of corrupt politicians.

In many ways, Nicha's grief-sharing with close family members as well as the public of large stands in stark contrast to common beliefs about grief such as those Katherine Walsh (2012: 100) refers to: "time heals all wounds," and "people find it too painful to talk about their loss." From April 10, 2010 to the present, more than four years, Nicha's speeches and writings have explicitly merged with the deeply delicate feelings of loss and abandonment with her unquenchable thirst for solace and closure. Evidently Nicha's grief fuelled fortitude dramatically following to the government high-handed shenanigans over the scandalous amnesty bill. Such an attempt is certainly like an act to kill General Romklao brutally once again. Nicha suffered so much that it forced her scream out to all who would listen, especially those of PDRC who had made it blatantly clear via all media that they sought the immediate relinquishing of power of the "Shinawatra regime". On the PDRC stage, Nicha's physical manners and gestures displayed calmness and serenity and her eyes, in close up, shone clear but with a hint of profound suffering. Ever willing to share her experience 
of grief, Nicha's words were delivered in a cool and controlled voice but are obviously masking the disgust she felt in effort to pass the loathsome amnesty bill. It hinted at a great sadness and strongly reflected Nicha's true condition. This was never more obvious than in her recollections of General Romklao's heroic performance of duty, during a speech at the Constitution Monument on Rajadamnern Road, not far from the spot where he was fatally shot.

\section{Conclusion}

Nicha Hiranburana Thuvatham presented her grievances via the media in a plea for justice on behalf of her late husband, General Romklao Thuvatham. From selected media extracts containing Nicha's speeches and writings on the issue of her husband's murder and the devastating effect it had on her, it goes without saying that her primary strategies in the struggle over the issue were fundamentally guided by grief and the opportunities posed by the political movement that was mobilized in opposition to PM Yingluck Shinawatra's government. Nicha's emotional condition was compounded when the government sought to pass the amnesty bill in the early morning of November 1, 2013 and her sentiments were in many ways shared with the masses protest in those unscruplous political machinations, especially the People's Democratic Reform Committee (PDRC), rallied against the short-sighted and corrupt policies of PM Yingluck's government.

The strategies employed by Nicha impacted on and inspired the ideological pursuit of justice, peace through Dharmic principles, non -corruption, and patriotism among those who gathered to oust the corrupt Shinawatra regime. Nicha's mission in this context can be considered a part of her mourning for her husband and, essentially, a cathartic exercise in her search for solace. The ideologies Nicha created via the media reflect the power of the mass media in society. Mass media in this context provides a practical channel for an individual to take a role in political movement in society which essentially connects the world by internet. People are kept informed of the government's performance via such media. In addition, Nicha's act in this context mirrors the role of educated middle-class woman in the contemporary Thai political movement, and it partly reveals the huge community who share the pain of injustice caused by corrupt government. Importantly, the case of Nicha and General Romklao reflects the absolute failure of the justice system in Thailand to remain free and independent of political interference.

\section{Acknowledgements}

The author of this article gratefully thanks Ajarn Krittaya Akanisdha and Asst. Prof. Chutima Pragatwuttisarn, Ph.D. for their very kind help with English usage and vocabulary.

\section{References}

DP Youth Center. (2013). Be cognizant of the trick of the whitewashing Amnesty Act. [Graphics video presentation]. Retrieved January 11, 2014 from http://www.youtube.com/watch?v=G4dUvVwQdTc

From the bottom of Angkhana's heart to 'Poo, the rotten rice' on lawyer Somchai's disappearance case and DSI. (2013). Naewna. Retrieved February 9, 2014 from http://www.naewna.com/politic/44648

Hall, C. (2014). Bereavement theory: recent developments in our understanding of grief and bereavement. Bereavement Care, Apr; 33(1): 7-12. DOI: 10.1080/02682621.2014.902610

Juree V. (2008). Women in politics and women and politics: A socio-cultural analysis of the Thai context. In Iwanaga, I. (Ed.), Women and politics in Thailand (pp.27-53). (n.p.), Malaysia: NIAS Press.

LiveTV0012Th. (2013). 241113 Nicha Hiranburana Thuvatham at the People Forum, Rajdamnoen. [Video]. Retrieved November 24, 2013, from http://www.youtube.com/watch?v=ASiTRPL_W6U

McCargo, D. (2009). Thai Politics as Reality TV. The Journal of Asian Studies, 68(1), 7-19. Retrieved from http://www.jstor.org/stable/ 20619668

Nakarin M. (Ed.). (2011). The disappearance of lawyer Somchai Neelapaijit. Retrieved from http://kpi.ac.th/wiki/index.php/\%e0\% b8\%81\%e0\%b8\%b2\%e0\%b8\%a3\%e0\%b8\%ab\%e0\%b8\%b2\%e0\%b8\%a2\%e0\%b8\%95\%e0\%b8\%b1\%e0\%b8\%a7\%e0\%b8\%82 \%e0\%b8\%ad\%e0\%b8\%87\%e0\%b8\%97\%e0\%b8\%99\%e0\%b8\%b2\%e0\%b8\%a2\%e0\%b8\%aa\%e0\%b8\%a1\%e0\%b8\%8a\%e0\% b8\%b2\%e0\%b8\%a2 \%e0\%b8\%99\%e0\%b8\%b5\%e0\%b8\%a5\%e0\%b8\%b0\%e0\%b9\%84\%e0\%b8\%9e\%e0\%b8\%88\%e0\%b8\%b $4 \% \mathrm{e} 0 \% \mathrm{~b} 8 \% 95 \% \mathrm{e} 0 \% \mathrm{~b} 8 \% \mathrm{a3}$

Nicha feels sympathy with the bereaved and writes a letter to encourage Suthin's wife to stand firm for 'Look-Kaew.' (2014). Naewna. Retrieved January 31, 2014 from http://www.naewna.com/politic/88025

Nicha H. T. (Ed.). 1st ed. (2011). In the memory of love. Bangkok: Aaroon Karn Pim.

Nicha urges government officers to take responsibilities for their duties and suggests 'Poo' who has never been bereaved of her own husband to take back her words on forgiving the convict. (2013). ASTV Manager Online. Retrieved November 24, 2013 from 
http://manager.co.th/Politics/ViewNews.aspx?NewsID=9560000146009

Nostitz, N. (2011). Red vs. yellow volume 2: Thailand's political awakening. Bangkok: White Lotus Press.

Pak-Soi-Roi-Neung [Radio Program] (Interview with Nicha Hirunburana Thuvatham). (2014, January 20). Bangkok, FM 101 Radio Report One: Producer.

Prarajawarakhun. (n.d.). Luang-Poo-Fark-Wai (Dharma from Luang-Poo). Bangkok: (n.p.l.)

Surin M. (2007). Learning From The 19 September Coup: Advancing Thai-style Democracy?. Southeast Asian Affairs. pp. 340-59. Retrieved from http://www.jstor.org/stable/27913340

Suteera V., \& Maytinee B. (2008). NGO advocacy for women in politics in Thailand. In Iwanaga, I. (Ed.), Women and politics in Thailand (pp.54-94). (n.p.), Malaysia: NIAS Press.

Thailand signs the International Convention on the Protection of All Persons from Enforced Disappearance. (2012). Human Rights. Retrieved June 24, 2014 from http://www.mfa.go.th/humanrights/news/1-latest-news/167--thailand-signs-the-internationalconvention-on-the-protection-of-all-persons-from-enforced-disappearance

Thompson, W. S. (2014). Thai coup holds promise of democracy. Los Angeles Times. Retrieved from http://www.latimes.com/opinion/ op-ed/la-oe-0529-thompson-thai-coup-20140529-story.html

Travers, B., Ali, N., \& Kolkiewicz, L. (2013). Bereavement in primary care mental health. Mental Health in Family Medicine, 10(4): $223-9$. Retrieved from http://eds.b.ebscohost.com/eds/pdfviewer/pdfviewer?sid=68d2bf26-aac3-42b7-b901-a93f9148443e\%40 sessionmgr113\&vid=4\&hid=101

Walsh, K. (2012). Grief and Loss: Theories and skills for the helping professions. $2^{\text {nd }}$ Ed. Boston: PEARSON. 